\title{
ANALISIS LITERASI INFORMASI PEMAKAI TAMAN BACAAN MASYARAKAT
}

\author{
Sri Ati Suwanto ${ }^{1}$ \\ ${ }^{1}$ Program Studi Ilmu Perpustakaan Universitas Diponegoro \\ 1tikasuwanto@gmail.com
}

ABSTRACT - This research examines about user information literacy community Reading Park. Community Reading Park that made the sample in this study is the community Reading Park in the city of Semarang, represented by the community Reading Park in Semarang Semarang, North West and South Semarang. The reason for the election of three subthis is because in three sub-this is the many community Reading Park active, besides keterbatasn research time. Information Literacy at TBM there is very important to be examined because the user community Reading Park is most is the karanng taruna who have dropped out of school and the mother of the housewife, which is difficult to get the reading in school library. This research uses the Literature Review or reviews the literature as a method of research types of research is qualitative research with the data type also qualitative data and data collection methods using the document. Data analysis used Qualitative analysis. Research results show that many developed countries that use Information Literacy to improve the quality of education in the community. There are some models of Information Literacy is applied. In Indonesia, the government based the development of slimming education with developing community Reading Park (TBM). From some of the community Reading Park has examined, most of the user community Reading Park in Semarang City Sub-district have been implementing Information Literacy, proved that they be aware of the information needed and they know how to search for and use it. They use the information they can according to their needs. There are used to working on the task to develop business and the household business them.

Keywords: Information Literacy, User studies, Community Reading Park
ABSTRAK - Penelitian ini mengkaji tentang literasi informasi pemakai TBM. TBM yang dijadikan sampel dalam kajian ini adalah TBM di kota Semarang, yang diwakili TBM di daerah Semarang Utara, Semarang Barat dan Semarang Selatan. Alasan pemilihan tiga kecamatan ini adalah karena di tiga kecamatan inilah banyak TBM yang aktif, disamping keterbatasn waktu penelitian. Literasi informasi di TBM sangat penting untuk dikaji, karena pemakai TBM ini sebagian besar adalah para karanng taruna yang telah putus sekolah dan ibu-ibu rumah tangga, yang sulit mendapatkan bacaan di perpustakaan sekolah. Penelitian ini menggunakan Literature Review atau tinjauan literature sebagai metode penelitiannya Jenis penelitiannya adalah penelitian kualitatif dengan jenis data juga data kualitatif, dan metode pengumpulan data menggunakan dokumen. Analisis data yang digunakan analisis kualitatif. Hasil penelitian menunjukkan bahwa banyak negara-negara maju yang menggunakan Literasi Informasi untuk meningkatkan kualitas pendidikan masyarakatnya. Ada beberapa model Literasi Informasi yang diterapkan. Di Indonesia, pemerintah memprogramkan pengembangan progarm pendidikan dengan mengembangkan Taman Baca Masyarakat (TBM). Dari beberapa TBM yang telah diteliti, sebagian besar pemakai TBM di kecamatan Kota Semarang telah menerapkan Literasi Informasi, terbukti bahwa mereka menyadari akan informasi yang dibutuhkannya, dan mereka tahu bagaimana cara mencari serta menggunakannya. Mereka menggunakan informasi yang telah mereka dapat sesuai dengan kebutuhan mereka

Kata kunci: Literasi Informasi, Kajian Pemakai, Taman Bacaan Masyarakat 


\section{PENDAHULUAN}

Peningkatan Kualitas Sumber Daya Manusia (SDM) telah ditekankan dalam Undang-Undang No.20 Tahun 2003 melalui pendidikan. Pendidikan dapat diperoleh melaui jalur formal dan nonformal. Hal ini perlu dilakukan untuk mengantisipasi dampak dari globalisasi terutama yang terkait dengan teknologi informasi.

Meningkatkan kualitas masyarakat baik dari segi ekonomi, pendidikan dan kesehatan merupakan tugas Pendidikan Luar Sekolah baik secara konseptor maupun praktik langsung. Dalam hal ini perlu adanya pengidentifikasian secara dini demi menemukan potensi yang dapat diangkat untuk meningkatkan kualitas masyarakat tersebut dan sudah barang tentu diperlukan instrumen yang sangat penting bagi setiap bangsa untuk meningkatkan daya saingnya dalam tatanan masyarakat dunia global. Banyak negara maju yang selalu membangun dunia pendidikannya tanpa henti. Amerika Serikat, misalnya selama bertahun-tahun sangat gencar memikirkan peningkatan kualitas pendidikan. Negara adidaya ini sadar bahwa kualitas pendidikan sangat menentukan masa depan bangsanya (Suyanto, Kompas, 2 Maret 2003).

Salah satu program pendidikan sebagai tindak lanjut dan implementasi program pemerintah yang turut mendukung keberhasilan pembangunan dunia pendidikan adalah adanya pengembangan Taman Bacaan Masyarakat (TBM). Pengembangan program pendidikan berupa program Pengembangan Taman Bacaan Masyarakat (TBM) adalah salah satu program pemerintah yang mengacu pada Undang-Undang Republik Indonesia Nomor 20 tahun 2003 tentang
Sistem Pendidikan Nasional, pasal 26 ayat (4), tercantum bahwa satuan pendidikan non formal terdiri atas lembaga kursus, lembaga pelatihan, kelompok belajar, pusat kegiatan belajar masyarakat, majelis taklim, serta satuan pendidikan yang sejenis. Dengan kegiatan TBM diharapkan pula dapat meningkatkan kemampuan, pengetahuan, keterampilan, dan memperluas wawasan bagi mereka yang telah melek aksara, serta bagi mereka yang putus sekolah atau tamat sekolah tetapi tidak melanjutkan sebagai bekal untuk mengembangkan diri, bekerja atau berusaha secara mandiri dalam setiap aktivitas mereka dalam kehidupan di masyarakat.

Tercatat sekitar 5.000 taman bacaan masyarakat (TBM) di seluruh Indonesia berpotensi mengembangkan program literasi lokal dari komunitas lokal. Selama ini, sejumlah fasilitas membaca, seperti perpustakaan, terasa menakutkan karena terkesan hanya orang sekolahan yang masuk ke dalam. TBM bisa berada di garda depan pemberantasan buta aksara dan menumbuhkan minat baca karena mudah diakses masyarakat, tidak eksklusif, dan membumi. Pada TBM, warga setempat dapat mengakses berbagai referensi, sekaligus menjadi wadah bagi komunitas untuk beraktivitas sesuai karakter dan potensi daerah tersebut. Supaya masyarakat yang ikut dalam proses pembelajaran tersebut terus belajar membaca, maka keberadaan TBM sangat diperlukan sekali. Dengan adanya TBM, masyarakat bisa mendapatkan kesempatan belajar mandiri atau mendapatkan informasiinformasi untuk memenuhi kebutuhan mereka.

Peningkatan kualitas sumber daya masyarakat dalam bentuk program taman bacaan ini telah 
dirintis sejak tahun lima puluhan berupa program kegiatan Taman Pustaka Rakyat (TPR), kemudian diperbaharui pada tahun 1992/1993 dengan adanya program kegiatan TBM. Dengan Program kegiatan TBM ini diharapkan nantinya dapat mewujudkan masyarakat gemar belajar (learning society) dengan salah satu indikatornya berupa masyarakat gemar membaca (reading society).

Selain itu, dengan kegiatan TBM ini diharapkan pula dapat meningkatkan kemampuan, pengetahuan, keterampilan, dan memperluas wawasan bagi mereka yang telah melek aksara, serta bagi mereka yang putus sekolah atau tamat sekolah tetapi tidak melanjutkan sebagai bekal untuk mengembangkan diri, bekerja atau berusaha secara mandiri dalam setiap aktivitas mereka dalam kehidupan di masyarakat.

Melek informasi sama artinya dengan literasi informasi. Pengertian Literasi informasi dalam penelitian ini adalah seperangkat keterampilan untuk mengenali kapan informasi dibutuhkan, baik itu untuk kepentingan akademisi ataupun pribadi, termasuk lingkup tempat kerja; melalui proses pencarian, penemuan dan pemanfaatan informasi dari beragam sumber; serta mengkomunikasikan pengetahuan baru ini dengan efektif dan efisien.

Karena adanya keterkaitan antara TBM dan Literasi Informasi, maka muncul permasalahan bagaimana literasi Informasi pemakai TBM. Oleh karena itu, maka penelitian ini akan menganalisisi literasi informasi pemakai TBM. Pemakai TBM dalam penelitian ini dibatasi hanya di tiga kecamatan di Kota Semarang.Tujuan dari penelitian ini adalah agar dapat diketahui oleh masyarakat luas literasi informasi pemakai TBM yang akhirnya dapat meningkatkan TBM tersebut. Penelitian ini sangat penting dilakukan, karena pemakai TBM sebagian besar adalah para karang taruna yang sudah putus sekolah dan ibu-ibu rumah tangga yang tidak dapat atau sulit meminjam di perpustakaan-perpustakan sekolah ataupun perpustakaan umum, karena asumsi mereka perpustakaan hanya untuk orang yang sekolah, dismping penulis sangat sulit menemukan artikel tentang literasi informasi pemakai TBM. Oleh karena itu penulis mencoba menggalinya dari beberapa sumber.

\section{TINJAUAN PUSTAKA}

Pengertian Literasi Informasi dapat diterjemahkan menjadi melek informasi, atau ada yang menyebutnya sebagai keberinformasian (Bahtar, dkk. 2009 dan Soedarsono 2007). Sedangkan menurut Wesleyan University literasi informasi adalah:

"a crucial skill in the pursuit of knowledge. It involves recognizing when information is needed and being able to efficiently locate, accurately evaluate, effectively use, and clearly communicate information in various formats."

Dari definisi tersebut dapat diartikan bahwa literasi informasi adalah keterampilan penting dalam pencarian pengetahuan, yang meliputi menyadari kapan informasi dibutuhkan dan dapat ditemukan secara efisien, dievaluasi, digunakan secaraefektif, dan dikomunikasikan dengan jelas di lingkungannya. Senada dengan pengertian literasi informasi dari Universitas Wesleyan, UNESCO mendeskripsikan bahwa Literasi 
informasi mengarahkan pengetahuan akan kesadaran dan kebutuhan informasi seseorang, dan kemampuan untuk mengidentifikasi, menemukan, mengevaluasi, mengorganisasi dan secara efektif menciptakan, menggunakan, mengomunikasikan informasi untuk mencari solusi atas masalah yang dihadapi; juga merupakan persyaratan untuk berpartisipasi dalam masyarakat informasi, dan merupakan hak asasi manusia untuk belajar sepanjang hayat (US National Commission on Library and Information Science, 2003). Sementara itu Komisi literasi informasi American Library Association (ALA) yang bertugas mengkaji peran informasi di dunia pendidikan, bisnis, pemerintahan, dan kehidupan sehari-hari dalam laporan akhirnya pada tahun 1989 menyimpulkan bahwa:

"Information literate people are those who have learned how to learn. They know how to learn because they know how knowledge is organized, how to find information and how to use information in such a way that others can learn from them. They are people prepared for lifelong learning, because they can always find the information needed for any task or decision at hand. (ALA, 1989, p.1)"

Artinya yaitu orang yang berinformasi (literate) adalah mereka yang telah belajar bagaimana belajar. Mereka mengetahui bagaimana harus belajar karena mereka mengetahui organisasi pengetahuan, memahami cara menemukan informasi, dan menggunakan/ memanfaatkan informasi sehingga pihak lain dapat belajar darinya. Mereka adalah orang yang disiapkan untuk belajar sepanjang hayat karena mereka selalu dapat menemukan informasi yang diperlukan untuk melaksanakan tugas atau mengambil keputusan. Senada dengan definisi dari ALA, dari Pusat Pengembangan Bahasa menjabarkan bahwa Literasi informasi adalah serangkaian kemampuan yang dibutuhkan orang untuk mengenali kapan informasi dibutuhkan; mengetahui di mana informasi tersebut bisa didapatkan; mengevaluasi dan menggunakan informasi yang diperlukan tersebut seefektif mungkin.

Dari definisi-definisi di atas, maka dapat ditarik kesimpulan bahwa literasi informasi adalah seperangkat keterampilan untuk mengenali kapan informasi dibutuhkan, baik itu untuk kepentingan akademisi ataupun pribadi, termasuk lingkup tempat kerja; melalui proses pencarian, penemuan dan pemanfaatan informasi dari beragam sumber; serta mengkomunikasikan pengetahuan baru ini dengan efektif dan efisien.

Secara umum, pemahaman yang terkandung dalam makna literasi informasi adalah:

a.Literasi informasi merupakan proses belajar bagaimana caranya belajar

b.Keterampilan literasi informasi mencakup pemahaman dan kemampuan seseorang untuk:

1) Menyadari kapan informasi itu diperlukan

2) Menemukan informasi

3) Mengevaluasi informasi

4) Menggunakan informasi yang diperoleh dengan efektif

5) Mengkomunikasikannya dengan etis

Dari definisi tersebut kemudian muncul pilarpilar literasi informasi yang menunjukkan kemampuan yang harus dimiliki untuk menjadi orang yang literate. The SCONUL working group 
on Information Literacy (2006) mendeskripsikan 7 pilar literasi informasi, yaitu:

1.Kemampuan untuk menyadari kebutuhan informasi;

2.Kemampuan untuk membedakan cara memenuhi kesenjangan informasi;

3.Kemampuan untuk membangun strategi menemukan informasi;

4.Kemampuan untuk mendapatkan dan mengakses informasi;

5.Kemampuan untuk membandingkan dan mengevaluasi informasi yang didapatkan dari berbagai sumber;

6. Kemampuan untuk mengorganisisr, menerapkan dan mengkomunikasikan informasi kepada sesama teman dengan cara yang tepat, dan

7.Kemampuan untuk memadukan dan membangun informasi yang ada, dan mengkontribusikan menjadi pengetahuan baru.

\section{Model Literasi Informasi}

Di samping 7 pilar literasi informasi yang menyampaikan urutan keterampilan yang dibutuhkan untuk dapat menjadi orang yang literate, ada berbagai macam model literasi informasi. British Model yang dikembangkan oleh Michael Marland pada tahun 1981. dalam bukunya yang berjudul Information Skills in the Secondary Curriculum merumuskan sembilan langkah dalam memecahkan masalah yaitu:

a. Memformulasikan dan menganalisa kebutuhan

b. Mengidentifikasi dan memeriksa sumbersumber informasi

c. Menelusur dan menemukan sumber-sumber informasi d. Menguji, memilih sumber-sumber informasi

e. Mengintegrasikan sumber-sumber informasi tersebut

f. Menyimpan dan mensortir informasi

g. Menginterpretasikan, menganalisa, mensintesiskan dan mengevaluasi informasi

h. Mempresentasikan atau mengkomunikasikan informasi

i. Mengevaluasi.

\section{Model the Big $6^{\mathrm{TM}}$}

Dari Amerika Serikat, sebuah model yang cukup terkenal dan banyak digunakan di sekolah adalah Big $6^{\mathrm{TM}}$ yang dikembangkan oleh Michael B.Eisenberg and Robert E. Berkowitz dari Amerika Serikat. Enam langkah ini adalah:

1. Penentuan tugas atau masalah

2. Strategi pencarian informasi

3. Pencarian sumber informasi yang diperlukan

4. Pemanfaatan informasi yang sudah diperoleh

5. Pengintegrasian informasi yang diperoleh dari sumber-sembert tersebut

6. Pengevaluasian terhadap hasil informasi yang diperoleh dan proses pemecahan masalahnya.

Model The Big $6^{\mathrm{TM}}$ sangat populer di Amerika Serikat dan di negara-negara yang sudah menyadari pentingnya implementasi literasi informasi dalam proses belajar mengajar di sekolah. Selain itu kedua pengembangnya secara aktif dan berkelanjutan mengembangkan model ini dengan mengeluarkan terbitan-terbitan yang bermanfaat bagi pemakainya. 


\section{Model Empowering8}

Empowering 8 adalah sebuah model yang dirancang khusus untuk kepentingan orang-orang Asia dirumuskan dalam sebuah pertemuan International Workshop on Information Skills for Learning yang diselenggarakan oleh IFLA/ALP dan NILIS di University of Colombo, Sri Lanka pada tahun 2004 dengan peserta dari negaranegara Asia. Model ini dipercaya sebagai salah satu model yang dapat langsung diimplementasikan oleh negara-negara di Asia dan juga dianggap memiliki pendekatan yang memberikan sebuah lingkungan pembelajaran yang lebih aktif, melibatkan siswa dan mengandung keterampilan superior. Ke delapan langkah tersebut adalah (Perpusnas, 2012):

1. Mengidentifikasi masalah;

2. Mengeksplorasi sumber informasi

3. Memilih sumber informasi

4. Menyusun informasi yang diperoleh

5. Menciptakan sebuah pengetahuan baru dari informasi yang terkumpul sebagai jawaban dari masalah

6. Mempresentasikan pengetahuan baru yang sudah tercipta

7. Memberi penilaian terhadap pengetahuan baru tersebut

8. Mengaplikasikan pengetahuan baru tersebut.

Dari beberapa model literasi informasi tersebut di atas, maka tampak jelas bahwa literasi informasi penting untuk siswa, maupun masyarakat lain pada umumnya untuk mengenali informasi yang dibutuhkan, menemukan informasi tsb. dan akhirnya menjadikannya pengetahuan baru. Literasi informasi juga sangat penting untuk masyarakat pemakai TBM, karena pemakai TBM tsb sebagian besar adalah siswa sekolah dasar dan karang taruna di perkampungan-perkampungan yang tersebar di seluruh Indonesia. Mereka sebagian besar tidak dapat mengakses perpustakan-perpustakaan, karena pada umumnya perpustakaan berdiri di lembaga pendidikan, dan pemakainya adalah orang-orang yang berada di lingkup lembaga pendidikan tersebut.

\section{METODE PENELITIAN}

Metode penelitian yang digunakan dalam tulisan ini adalah tinjauan literatur dari para pakar dan hasil penelitian yang pernah dilakukan oleh Jurusan Ilmu Perpustakaan UNDIP. Sedangkan jenis penelitian ini adalah penelitian kualitatif dan data yang didapat juga data kualitatif yang berasal dari sumber primer dan sekunder, yaitu hasil penelitian dan artikel-artikel dari para pakar. Pengumpulan data dilakukan dengan menggunakan dokumen, dan analisis data dilakukan secara kualitatif.

\section{HASIL PENELITIAN}

Pengembangan program pendidikan berupa program Pengembangan Taman Bacaan Masyarakat (TBM) adalah salah satu program pemerintah yang mengacu pada Undang-Undang Republik Indonesia Nomor 20 tahun 2003 tentang Sistem Pendidikan Nasional, pasal 26 ayat (4), tercantum bahwa satuan pendidikan non formal terdiri atas lembaga kursus, lembaga pelatihan, kelompok belajar, pusat kegiatan belajar masyarakat, majelis taklim, serta satuan pendidikan yang sejenis. Melalui kegiatan 
membaca maka masyarakat dapat belajar dan memperluas wawasan, memperoleh berbagai informasi yang bermanfaat, dan dapat menghibur diri. Salah satu cara untuk mencerdaskan kehidupan bangsa adalah dengan menggalakkan budaya membaca.

Selain itu, dengan kegiatan TBM ini diharapkan pula dapat meningkatkan kemampuan, pengetahuan, keterampilan, dan memperluas wawasan bagi mereka yang telah melek aksara, serta bagi mereka yang putus sekolah atau tamat sekolah tetapi tidak melanjutkan sebagai bekal untuk mengembangkan diri, bekerja atau berusaha secara mandiri dalam setiap aktivitas mereka dalam kehidupan di masyarakat ( Hamid, 2008).

Taman bacaan masyarakat adalah lembaga untuk melayani kepentingan penduduk yang tinggal di sekitarnya. Mereka terdiri atas semua lapisan masyarakat tanpa membedakan latar belakang sosial, ekonomi, budaya, agama, adat istiadat, tingkat pendidikan, umur dan lain sebagainya (Pustakaindonesia, 2012)

Tujuan dari kegiatan ini adalah mewujudkan masyarakat gemar belajar (learning society), salah satu indikatornya terlihat dari masyarakat yang gemar membaca (reading society).

Salah satu instrumen untuk membangkitkan budaya gemar belajar melalui masyarakat gemar membaca adalah dengan tersedianya Taman Bacaan Masyarakat (TBM). TBM adalah suatu lembaga/tempat yang menyediakan bahan bacaan yang dibutuhkan oleh masyarakat, dan sebagai tempat penyelenggaraan program pembinaan kemampuan membaca dan belajar masyarakat (Departemen Pendidikan Nasional, 1989). Tujuan diselenggarakannya taman bacaan selain untuk mewujudkan masyarakat gemar membaca, juga dimaksudkan untuk mendukung pendidikan keaksaraan (Departemen Pendidikan Nasional, 2008). Keaksaraan menurut H.S Bhola dikatakan sebagai instrumental yang terkait dengan peradaban manusia berupa kemampuan baca-tulis sebagai induk bahasa yang digunakan oleh setiap bangsa di dunia. Kemampuan keaksaraan juga sangat berhubungan dengan pengembangan budaya, termasuk ikteraksi semua faktor yang menunjang keaksaraan itu sendiri (Departemen Pendidikan Nasional, 2005).

Taman Bacaan Masyarakat merupakan salah satu sarana dan program dampingan yang pada intinya berupaya menstimulasi dan mendukung ke arah keberlanjutan Program Pendidikan Keaksaraan. Untuk memelihara keberlangsungan penyelenggaraan TBM diperlukan berbagai alternatif dalam pengelolaannya, sehingga warga belajar dapat memanfaatkan TBM secara maksimal (Hatimah, Ihat, dkk, 2007).

Tercatat sekitar 5.000 taman bacaan masyarakat (TBM) di seluruh Indonesia berpotensi mengembangkan program literasi lokal dari komunitas lokal. Selama ini, sejumlah fasilitas membaca, seperti perpustakaan, terasa menakutkan karena terkesan hanya orang sekolahan yang masuk ke dalam. TBM bisa berada di garda depan pemberantasan buta aksara dan menumbuhkan minat baca karena mudah diakses masyarakat, tidak eksklusif, dan membumi. Pada TBM, warga setempat dapat mengakses berbagai referensi, sekaligus menjadi wadah bagi komunitas untuk beraktivitas sesuai karakter dan potensi daerah tersebut. 


\section{Latar belakang berdirinya TBM}

Bangsa yang maju adalah bangsa yang berbudaya. Tidak disangkal lagi bahwa, bangsa Indonesia adalah bangsa yang kaya akan aneka ragam budaya yang mengagumkan. Akan tetapi, budaya luhur yang telah diwariskan itu seperti habis ditelan roda zaman peradaban, salah satu penyebabnya adalah karena generasi penerusnya tidak gemar membaca dan mempelajari sejarah.Oleh karena itu, salah satu cara untuk mempertahankan budaya luhur bangsa adalah dengan melahirkan generasi senang baca. Ada semacam hubungan yang kuat antara bangsa yang maju dengan tingginya minat baca. Artinya semakin tinggi kebiasaan membaca masyarakatnya maka semakin maju pula bangsanya.Jika ada pertanyaan, bagaimana sebuah bangsa masuk kategori maju atau terpuruk? Jawabannya, lihatlah mentalitas belajar masyarakatnya, dan buku merupakan jendela yang dapat membuka wawasan dan menciptakan perubahan.Untuk melahirkan generasi seperti itu diperlukan sarana pendukung, dan program pengadaan Taman Bacaan Masyarakat (TBM) adalah solusi terbaik yang bisa dilakukan.(Pemustaka, 2013).

Munculnya TBM diawali dengan runtuhnya rezim ord baru. Di awal tahun 1990 merupakan perubahan kala besar di Indonesia. Dimasa orde baru beberapa organisasi sosial kemasyarakatan, kepemudaan dan organisasi keagamaan pun dibatasi ruang geraknya. Akibatnya dengan lengsernya Presiden Suharto membuka kran reformasi di Indonesia dan membuka jalan yang lebih dinamis bagi masyarakat sipil di Indonesia. Akibat dampak dari krisis moneter yang terjadi tahun 1996 - 1998, menyebabkan banyak anak putus sekolah, bahkan menjadi anak jalanan. Dengan adanya reformasi, organisasi-organisasi sosial lebih leluasa bergerak, termasuk menyediakan layanan-layanan sosial. Banyak organisasi yang mendukung berdirinya Taman Bacaan. Haklev (2008) menybutkan bahwa mulai tahuntahun 2000 Taman Bacaan menjadi gerakan yang populer, dan pada 2001 Taman Bacaan tumbuh dengan pesat.

\section{Fungsi Taman Bacaan Masyarakat}

Fungsi dari Taman Bacaan Masyarakat adalah: 1. Sarana Pembelajaran bagi masyarakat. 2. Sarana hiburan (rekreasi) dan pemanfaatan waktu secara efektif dengan memanfaatkan bahan bacaan dan sumber informasi lain sehingga warga masyarakat dapat memperoleh pengetahuan dan informasi baru guna meningkatkan kehidupan mereka. 3. Sarana informasi berupa buku dan bahan bacaan lain yang sesuai dengan kebutuhan warga belajar dan masyarakat setempat (Kusnadi, 2008). Dari fungsi ini dapat dilihat bahwa secara fisik maupun psikologis keberadaan TBM sangat dibutuhkan oleh masyarakat terutama oleh masyarakat yang tidak mampu menyediakan bahan bacaan sendiri.

\section{Tujuan penyelenggaraan TBM}

TBM yang diselenggarakan oleh masyarakat dan untuk masyarakat bertujuan untuk memberi kemudahan akses kepada warga masyarakat untuk memperoleh bahan bacaan. Di samping itu, TBM berperan dalam meningkatkan minat baca, menumbuhkan budaya baca dan cinta buku bagi warga belajar dan masyarakat. Secara khusus 
TBM dimaksudkan untuk mendukung gerakan pemberantasan buta aksara yang antara lain karena kurangnya sarana yang memungkinkan para aksarawan baru dapat memelihara dan meningkatkan kemampuan baca tulisnya. TBM juga ditujukan untuk memperluas akses dalam memberikan kesempatan kepada masyarakat mendapatkan layanan pendidikan (Departemen Pendidikan Nasional, 2008).

\section{Literasi Informasi Pemakai (Pemustaka) TBM}

Bertolak dari pengertian Literasi informasi yang mengacu pada kemampuan mengenali kapan informasi dibutuhkan, dimana dan bagaimana mencarinya serta digunakan untuk apa, maka berikut ini akan dipaparkan literasi informasi pemakai TBM di kota Semarang.

Dari hasil penelitian perilaku masyarakat pesisir di kota Semarang (Sri Ati, dkk, 2013) dapat diketahui beberapa hal sebagai berikut:

1) Pengetahuan tentang Kebutuhan Informasi.

Pengetahuan tentang kebutuhan informasi pemakai TBM di kecamatan Semarang Utara (TBM Bangun Bangsa), cukup beragam sesuai dengan jenis pemakainya. Pemakai sebagian besar siswa kejar paket A, B, dan C. Mereka sebagian besar sudah mengetahui apa yang mereka butuhkan, karena mereka mencari informasi yang terkait dengan kegiatan pembelajaran mereka. Sedangkan sebagian lain adalah ibu-ibu yang menunggu anaknya belajar di PAUD. Sehingga mereka kurang mengerti kebutuhan mereka. Mereka mencari informasi hanya sekedar menghilangkan rasa jenuh dan untuk menghabiskan waktu.
Untuk kebutuhan informasi pemakai TBM di Semarang Selatan (TBM Mortir, Anggrek dan Ken Maos) sangat beragam. Mereka ada yang sudah kuliah (mahasiswa), karangtaruna, bapakbapak, dan juga ibu-ibu orang tua siswa yang menunggu anak-anak nya sekolah di PAUD sehingga sebagian besar belum mengetahui apa yang mereka butuhkan, karena mereka membaca hanya menunggu waktu saja.. Untuk kelompok mahasiswa sebagian besar sudah mengetahui informasi yang dibutuhkan, sedangkan bapakbapak dan ibu-ibu masih belum jelas apa yang mereka butuhkan. Mereka mencari informasi ke TBM hanya untuk mengisi waktu senggang saja dengan mencari Koran, buku-buku fiksi dan buku-buku tentang keterampilan.

\section{Pemakai TBM di Semarang Barat (TBM} Sasana Wiyata), sebagian besar telah mengetahui apa yang mereka butuhkan, karena didasarkan pada tugas yang diberikan oleh guru-guru sekolah mereka. Hal ini disebabkan karena pemakai di TBM- TBM tersebut sebagian besar adalah siswa Kejar Paket, Siswa SMU dan SMP dan SD. Tetapi ada juga ibu-ibu yang tergabung dalam kelompok keterampilan bekerjasama dengan PKK setempat, seperti pelatihan membuat baki lamaran, membuat tas mote, dan lain-lain. Kelompok ibu-ibu ini sebagian besar juga sudah mengetahui apa yang mereka butuhkan. Disamping itu banyak juga Karang Taruna yang datang ke TBM yang juga telah mengetahui apa yang mereka butuhkan, mereka mencari buku-buku keterampilan.

Jenis informasi yang dicari para Karang Taruna ini sebagian besar yang terkait dengan peningkatan pengetahuan mereka tentang keterampilan, berkebun dan memasak. Sedangkan 
para siswa sebagian besar mencari informasi tentang tokoh-tokoh kepahlawanan dan sejarah perjuangannya, dan yang lainnya fiksi dan hiburan. Sementara ibu-ibu mencari jenis informasi tentang keterampilan dan masak memasak, kesehtan dan ada juga tentang bisnis..

Bentuk atau media informasi yang dibutuhkan para pemakai TBM sebagian besar berupa buku dan majalah, yang lain ada beberapa yang mencari tabloid dan koran. Untuk pemakai TBM di Semarang Barat sebagian besar mencari jenis informasi berbentuk buku dan majalah, dan beberapa diantaranya ada yang mencari dari CDROM.

\section{2) Perilaku Pencarian Informasi}

Untuk mengetahui di mana dan bagaimana mencari informasi, maka dikaji tentang perilaku pencarian informasi. Dalam mencari koleksi mayoritas pemakaiTBM di Semarang Utara melakukannya dengan dua cara, yakni:

1. Langsung datang ke rak buku untuk mencari buku yang diinginkan.

2. Dibantu petugas TBM. Prosedurnya mereka menyampaikan kebutuhan informasi yang dibutuhkan lalu petugas mengambil di rak.

Apabila buku atau koleksi lain yang dicari tidak ditemukan di TBM, pemakai yang TBM Sasana Wiyata, yang sebagian besar siswa sekolah, mencarinya ke Perpustakaan Keliling yang datang ke sekolah mereka, dan jika masih belum menemukannya mereka mencari ke toko buku (membeli). Sedangkan pemakai di TBM.

Sedangkan pemakai TBM Semarang Selatan (TBM Mortir, Anggrek dan Ken Maos)juga langsung ke rak buku atau Tanya ke petugas dulu baru ke rak buku. Tetapi mereka tidak ada yang mengatakan membeli ke toko buku, tetapi sebagian yang lain yang statusnya mahasiswa, mereka mencari informasi ke perpustakaan di kampusnya atau ke Perpustakaan Daerah. Hal ini mungkin disebabkan karena mereka sebagian besar karang taruna, dan yang mahasiswa, mereka datang dari golongan menengah ke bawah.Untuk pemakai TBM di Semarang Barat (TBM Sasana Wiyata), cara mereka mencari informasi juga sama, yaitu langsung ke rak buku atau Tanya petugas. Jika tidak ketemu, para pemakai TBM Sasana Wiyata ini mencarinya ke Perpustakaan keliling yang datang secara berkala di sekolah mereka, dan sebgain kecil diantaranya membeli ke took buku.

3) Penggunaan Informasi.

Informasi yang sesbagian sudah diketahui oleh para pemakai TBM kemudian mereka gunakan untuk berbagai keperluan. Untuk pemakai TBM di Semarang Utara, yang statusnya mahasiswa, sebagian besar digunakan untuk mengerjakan tugas dari dosesn mereka; Sedangkan pemakai yang statusnya karang taruna informasi yang didapat digunakan untuk mengembangkan keterampilan mereka, dan untuk hiburan. Pemakai TBM yang statusnya ibu-ibu rumah tangga, informasi yang didapat digunakan untuk menambah pengetahuan tentang bisnis dan hiburan.

Pemakai di TBM Semarang Barat, informasi yang mereka dapatkan sebagian besar digunakan untuk menambah pengetahuan mereka, baik untuk membuat keterampilan, maupun untuk kegiatan bisnis. Sedangkan pemakai siswa sekolah, sebagian besar informasi yang didapat digunakan mengerjakan tugas dari guru sekolah mereka. 
Pemakai TBM yang statusnya ibu-ibu rumah tangga, informasi yang didapat digunakan untuk menambah pengetahuan tentang masak memasak dan meningkatkan keterampilan.

Informasi yang didapat oleh pemakai TBM di Semarang Selatan (TBM Mortir, Anggrek dan Ken Maos) digunakan untuk berbagai keperluan. Pemakai di TBM ini sebagian besar digunakan untuk menambah pengetahuan, dan untuk mengerjakan tugas dari dosen atau guru. Secara spesifik dapat dijelaskan bahwa pemakai dari kelompok siswa dan mahasiswa mengatakan bahwa informasi yang didapat digunakan untuk mengerjakan tugas sekolah atau kampus; Sedangkan para karang taruna dan ibu-ibu menyatakan bahwa informasi tsb digunakan untuk mengembangkan usha bisnis kelak seperti untuk bisnis perikanan, atau untuk membuat usaha katering.

\section{SIMPULAN}

Literasi informasi adalah seperangkat keterampilan untuk mengenali kapan informasi dibutuhkan, baik itu untuk kepentingan akademisi ataupun pribadi, termasuk lingkup tempat kerja; melalui proses pencarian, penemuan dan pemanfaatan informasi dari beragam sumber; serta mengkomunikasikan pengetahuan baru ini dengan efektif dan efisien. Hasil penelitian menunjukkan bahwa banyak negara maju yang menggunakan Literasi Informasi untuk meningkatkan kualitas pendidikan masyarakatnya. Ada beberapa model Literasi Informasi yang diterapkan di Indonesia, pemerintah memprogramkan pengembangan progarm pendidikan dengan mengembangkan Taman Baca Masyarakat (TBM). Dari beberapa
TBM yang telah diteliti, sebagian besar pemakai TBM di kecamatan Kota Semarang telah menerapkan Literasi Informasi, terbukti bahwa mereka menyadari akan informasi yang dibutuhkannya, dan mereka tahu bagaimana cara mencari serta menggunakannya. Mereka menggunakan informasi yang telah mereka dapat sesuai dengan kebutuhan mereka. Ada yang digunakan untuk mengerjakan tugas, mengembangkan bisnis, dan usaha rumah tangga mereka. Akan tetapi sebgian besar dari mereka tidak menguji dan memilih sumber informasi, karena keterbatasn sumber inforamsi yang tersedia.

\section{DAFTAR PUSTAKA}

Bahtar, Murni A, Arifah Sasmita, Sri Purnomowati. (2009). Literasi Informasi tenaga pendidik dan kependidikan Pendidikan Non Forma (PNF) di Provinsi DKI Jakarta. Baca, vol.30, no.2.

Departemen Pendidikan Nasional, UndangUndang No. 2/1989, Pasal 4. Sistem Pendidikan Nasional.

Departemen Pendidikan Nasional. (2008). Naskah Akademik Pengelola TamanBacaan Masyarakat (TBM). Direktorat Jenderal Peningkatan Mutu Pendidik dan Tenaga Kependidikan, Direktorat Pendidik dan Tenaga Kependidikan Nonformal, Jakarta.

Guahira. or. id. Minat Baca di Indonesia Buruk. 21 Oktober 2007.

Haklev, Stian. (2008). Mencerdaskan bangsa Suatu pertanyaan: Fenomena Taman Bacaan di Indonesia. Advanced Seminar in international Development Studies, IDSD01Y, Internatinal Development Studies, University of Toronto at Scarborough.

Hakley, Stian. (2008). Mencerdaskan Bangsa Suatu pertnyaan fenomena Taman Bacaan di Indonesia. Disampaikan pada Advanced Seminar in International Development Studies, IDSD01, International 
Development Studies, University of Toronto at Scarborough.

Hatimah, Ihat, dkk, (2007). Pengembangan Model Penyelenggaraan Taman Bacaan Masyarakat Dengan Sistem Sircle Time Sebagai Upaya Pelestarian Program Keaksaraan Fungsional. Data Penelitian UPI, Bandung.

Kusnadi, dkk. (2005). Pendidikan Keaksaraaan, Filosofi, Strategi, Implementasi. Jakarta: Departemen Pendidikan Nasional.

Pemustaka,

http://www.pemustaka.com/1000-taman-

bacaan-masyarakat-tbm-untukrakyat. html. [15 AGUSTUS, 2013]

Suwanto, Sri Ati, Yuli Rohmi, Heriyanto, Diah Setiyorini. (2013). Perilaku informasi pada masyarakat pesisir Kota Semarang: Studi kasus di Taman Bacaan Masyarakat di 3 kecamatan Kota Semarang.

The ALA/ACRL/STS Task Force on Information Literacy for Science and Technology. Information literacy standards for science and engineering/technology. (http://www.ala.org/ala/acrl/acrlstandards/i nfolitscitech.htm, diakses 26 Maret 2007).

UNESCO, (2007). Information for All Programme: "Understanding Information Literacy: A Primer". Paris: UNESCO.

US National Commission on Library and Information Science, (2003). Information Literacy.

http://www.nclis.gov/libinter/infolitconf\& meet/postinfolitconf\&meet/PragueDeclaration .pdf. [2 Agustus 2013]

Wesleyan University, home. (2013). Information Literacy. $\quad$ http://www.wesleyan.edu/libr/ guides/infolitdef.html [2 Agustus, 2013]. 